\title{
Aspartate Aminotransferase Activity after Gargling with Green Tea and Chlorhexidine Gluconate
}

\author{
Christian E. Suryanto ${ }^{1}$, Melanie S. Djamil ${ }^{2}$, Suzan Elias ${ }^{3}$, Isnani Jenie ${ }^{4}$ \\ ${ }^{1}$ Dental Science Master Program, Faculty of Dentistry, Trisakti University, Jakarta 11440, Indonesia \\ ${ }^{2}$ Department of Biochemistry, Faculty of Dentistry, Trisakti University, Jakarta 11440, Indonesia \\ ${ }^{3}$ Department of Prosthodontics, Faculty of Dentistry, Trisakti University, Jakarta 11440, Indonesia \\ ${ }^{4}$ Department of Orthodontics, Faculty of Dentistry, Trisakti University, Jakarta 11440, Indonesia \\ Correspondencee-mail to: christian_eka_s@yahoo.com
}

\begin{abstract}
Patients undergoing fixed orthodontic treatment are susceptible to dental plaque accumulation. Plaque can cause inflammation in gingiva. It could be assessed by aspartat aminotransferase (AST) in gingival crevicular fluid (GCF). Mouth rinse could be useful to reduce dental plaque accumulation during orthodontic treatment. Chlorhexidine gluconate is often used as mouth rinse in dental practice. On the other hand, green tea is one of natural ingredient that can be used for mouth rinse which is assumed could reduce plaque accumulation. Objectives: To compare the effect between green tea and chlorhexidine gluconate on AST activity in GCF in patient undergoing orthodontic treatment with molar band. Methods: An experimental study was conducted included forty adult subjects. They were randomized into two groups: green tea $(n=20)$ and chlorhexidine gluconate $(n=20)$. AST activity was measured before band insertion, 7 and 30 days after band insertion. One way and two-ways ANOVA were used to analyze the data. Results: The results showed significant difference of AST levels between before, 7 and 30 days after band insertion in the green tea groups $(p<0.05)$. In contrast, there was no significant differences of AST levels between before band insertion, 7 and 30 days after band insertion in the chlorhexidine gluconate groups $(p=0.049)$. There were no difference between each groups with two way ANOVA $(p<0.05)$. Conclusions: Gargle effect of green tea was as effective as chlorhexidine gluconate in reducing AST levels related to banded first molars in adolescents undergoing orthodontic treatment.
\end{abstract}

\begin{abstract}
ABSTRAK
Aktifitas aspartat amino transferase setelah berkumur dengan teh hijau dan klorheksidin glukonat. Perawatan ortodontik dapat meningkatkan akumulasi plak gigi. Plak dapat menyebabkan peradangan pada gingiva. Peradangan dapat dinilai dari kadar aspartat aminotransferase (AST) dalam cairan krevicular gingiva (CKG). Obat kumur bermanfaat untuk mengurangi akumulasi plak gigi selama perawatan ortodontik. Klorheksidin glukonat sering digunakan sebagai obat kumur. Teh hijau adalah salah satu bahan alam yang dapat digunakan untuk obat kumur yang dianggap dapat mengurangi akumulasi plak. Tujuan: Membandingkan efek antara teh hijau dan klorheksidin glukonat aktivitas AST di GCF pada pasien yang menjalani perawatan ortodontik dengan molar band. Metode: Studi eksperimental dilakukan terhadap 40 subjek dewasa. Subjek dibagi secara acak menjadi dua kelompok: teh hijau $(\mathrm{n}=20)$ dan klorheksidin glukonat $(\mathrm{n}=20)$. Aktivitas AST diukur sebelum pemasangan band, 7 dan 30 hari setelah pemasangan band. Uji ANOVA digunakan untuk menganalisis data. Hasil: Terdapat perbedaan signifikan antara kadar AST sebelum, 7 dan 30 hari setelah pemasangan band pada kelompok teh hijau $(p<0,05)$. Tidak ada perbedaan yang signifikan antara kadar AST sebelum pemasangan band, 7 dan 30 hari setelah pemasangan band pada kelompok klorheksidin glukonat $(p=0,049)$. Tidak ada perbedaan antara masingmasing kelompok $(p<0,05)$. Simpulan: Obat kumur teh hijau memiliki efektivitas yang sama dengan klorheksidin glukonat dalam mengurangi tingkat AST pada pasien ortodontik.
\end{abstract}

Key words: aspartate aminotransferase activity, chlorhexidine gluconate, green tea, orthodontic band 


\section{INTRODUCTION}

Fixed orthodontic appliances caused difficulties in brushing and resulted in an increased of dental plaque accumulation. An adequate plaque control was difficult in patients undergoing orthodontic treatment, particularly when bands, wires and ligatures were involved. ${ }^{1,2}$ The previous clinical trial showed the development of hyperplastic gingivitis within 1 to 2 months after placement of appliances. ${ }^{1}$

Mouth rinse could be useful to reduce dental plaque accumulation during orthodontic treatment. ${ }^{2,3}$ Chlorhexidine is an antibacterial and antiseptic agent that have been used widely in dentistry. It has been noted to be effective for plaque control and gingivitis without developing resistant organisms in the oral flora. ${ }^{2,4-9}$ It was stated that subjectwho used chlorhexidine gluconate for 30 seconds, twice a day, can maintain gingival health compared to one who did not gargle 3 months after orthodontic treatment. ${ }^{4}$ The previous clinical trial showed that a $0.2 \%$ chlorhexidine gluconate reduced the formation of plaque about $72 \%$ in first 3 days and $85 \%$ in 7 days. $^{5}$ Green tea is one of natural ingredient that can be used for mouth rinse to reduce plaque accumulation. ${ }^{3,10-12}$ Several studies have suggested that green tea catechins inhibit periodontal pathogens and the destruction of periodontal tissue. ${ }^{10}$ Green tea's catechin inhibits the growth of Porphyromonas gingivalis and the adherence of $P$. gingivalis onto human buccal epithelial cells. ${ }^{10,11,13}$

Inflammation due to plaque accumulation could be assessed by aspartate aminotransferase (AST) concentration in gingival crevicular fluid (GCF). ${ }^{14-18}$ AST is often used as an indicator to mark metabolic changes in periodontal tissue. Since this enzyme is normally confined to the cytoplasm, the increase in its extracellular levels is considered to be a sign of increased cell necrosis. ${ }^{15,18}$ Previous study assured that AST activity in GCF as an indicator of gingival inflammation. ${ }^{18}$ The objective of this study was comparing the effect of green tea and chlorhexidine gluconate on AST activity in GCF in patient undergoing orthodontic treatment with molar band.

\section{METHODS}

An experimental design was conducted in 40 adult subjects. They were randomized into two groups: green tea $(n=20)$ and chlorhexidine gluconate $(n=20)$. AST activity were measured before band insertion, 7 and 30 days after band insertion. The following inclusion criteria were used: (1) good oral hygiene; (2) good periodontal health first molar teeth, probing depth values not exceeding $2 \mathrm{~mm}$; (3) not taken antiinflammatory drugs in the month before the study; (4) no radiographic evidence of caries, periapical pathology or root resorption; (5) anchorage type A. The GCF of molar sampling was performed after isolating the area with cotton rolls and air-dried.The collection of GCF was done before band insertion, 7 days and 30 days after band insertion. The GCF was collected using $2 \mathrm{~mm} \times 8 \mathrm{~mm}$ Whatmann $3 \mathrm{MM}$ filter paper inserted $1 \mathrm{~mm}$ into the gingival crevices and left for 30 seconds. Immediately after collection, it was transferred into $1.5 \mathrm{~mL}$ tube and kept in $-80^{\circ} \mathrm{C}$ temperature at Makmal Terpadu Imunoendokrinologi, Universitas Indonesia.

The AST activity was measured with spectrophotometer (BIO-RAD SmartSpec V3.00.13.e- Italy) with aspartate aminotransferase FS DGKC reagent. $100 \mu \mathrm{L}$ of GCF and $1000 \mu \mathrm{L}$ reagent were mixed for the assay of AST activity determination. The absorbance was measured at 340nm at 1,2 and 3 minutes. SPSS program was used for data analysis. Each data set was tested for normality with the Kolmogorov-Smirnov test.A one-way and twoway ANOVA were used to assess the AST activity on different measurement time and the difference between green tea's and chlorhexidine gluconate's groups.

\section{RESULTS}

Mean and standard deviation showed that the data was normal with Kolmogorov-Smirnov test. The AST activity in the green tea's groups were $33.85 \pm 11.72 \mathrm{U} / 1$ (before band insertion); $24.95 \pm 11.25 \mathrm{U} / 1$ ( 7 days after band insertion); $23.95 \pm 10.03 \mathrm{U} / 1$ (30 days after band insertion). The results showed significant difference of AST levels between before band insertion and 30 days after band insertion in the green tea's groups $(p<0.05)$. The AST activity in the chlorhexidine gluconate's groups were $36.85 \pm 12.10 \mathrm{U} / 1$ (before band insertion); $27.60 \pm 10.22 \mathrm{U} / 1$ (7 days after band insertion); $27.20 \pm 17.61 \mathrm{U} / 1$ (30 days after band insertion). There was no significant differences of AST levels between before band insertion, 7 days and 30 days after band insertion in the chlorhexidine gluconate's groups $(p=0.049)$. The tests were performed using one way ANOVA. There was no significant difference between each groups with two-way ANOVA $(p>0.05)$.

\section{DISCUSSION}

AST is an intracellular, cytoplasmic enzyme that is released extracellularly upon cell death. Its activity in the extracellular environment can be considered as an indicator of cell necrosis. AST activity has been monitored in the gingival crevicular fluid during periodontal inflammation or orthodontic treatment. ${ }^{14-18}$ Samples of this study were GCF on banded first molar with anchorage was type A. This anchorage is a maximal anchorage. ${ }^{19}$ The use of this anchorage, to avoid the confusion of AST activity, because of the tooth movement can increase the AST activity. ${ }^{20}$ 
The results showed significant difference of AST levels between before band insertion and 30 days after band insertion in the green tea's groups $(p<0.05)$. Previous studies suggested that green tea's catechin has a preventive effect against the development of periodontal disease. ${ }^{10,11}$ This study showed that green tea's catechin could decrease the AST activity. Green tea was a popular drink, its components, such as catechin, had a preventive effect against cancer development and cardiovascular disease in experimental and epidemiologic studies. Several in vitro studies have suggested that green tea's catechins, such as epigallocatechingallate (EGCg), inhibit periodontal pathogens and the destruction of periodontal tissue..$^{10,11,13}$

There was no significant difference of AST levels between before band insertion, 7 days and 30 days after band insertion in the chlorhexidine gluconate's groups $(p=0.049)$. However, the AST levels tend to decrease after gargling with chlorhexidine gluconate. There was no significant difference of AST level could be caused that before the patients gargle with mouth rinse, they brushed their teeth with toothpaste containing sodium lauryl sulphate. Chlorhexidine is a cationic and forms salts of low solubility with anions, resulting in a reduced antimicrobial effect. Such an anionic is sodium lauryl sulphate, which is used as a detergent in toothpaste. ${ }^{22}$ Catechin in green tea may not be affected by the effect of toothpaste containing sodium lauryl sulphate. To the best of our knowledge no research assessing the relationship between green tea and sodium sulphate lauryl. Therefore, further research needs to be done for showing their relationship. However, previous studies suggested that the use of chlorhexidine mouth rinse can be beneficial to orthodontic patients in maintaining better oral hygiene. Reduced plaque retention in those patients who use the chlorhexidine. ${ }^{1}$

This investigation corroborates that an inflammatory process takes place during application of mechanical force to teeth. Although this inflammation was considered relatively aseptic, additional inflammation, such as that induced by plaque accumulation, must be avoided during orthodontic treatment. ${ }^{21}$ There was no difference between green tea's groups and chlorhexidine gluconate's groups with two way ANOVA $(p>0.05)$. This investigation showed that use of green tea was as effective as chlorhexidine gluconate in reducing AST levels related to banded first molars in adolescents undergoing orthodontic treatment.

Orthodontic appliances hinder plaque removal from the actions of brushing, mastication and salivary flow. Mouth rinse could be used during the active phase of orthodontic treatment to reduce the bacterial plaque accumulation, thereby improving the gingival conditions and possibly reducing the incidence of caries and periodontal disease in these patients. Mouth rinse should be used adjunctively for orthodontic patients who have difficulty maintaining plaque control by mechanical means alone. However, these patients should be reminded that the mouth rinse are not substitutes for thorough brushing and interproximal cleaning.

\section{CONCLUSIONS}

The conclusions for this research that there was significant difference of AST levels between baseline band insertion and 30 days after band insertion in the green tea group. This study showed that green tea's catechin could decrease the AST baseline activity before band insertion until 30 days after band insertion. There was no significant difference of AST levels between before band insertion and 7 days after band insertion. This investigation showed that the use of green tea was as effective as chlorhexidine gluconate in reducing AST levels related to banded first molars in adolescents undergoing orthodontic treatment.

\section{REFERENCES}

1. Anderson GB, Bowden J, Morrison EC, Caffesse RG. Clinical effects of chlorhexidine mouth washes on patients undergoing orthodontic treatment. Am J Orthod Dentofac Orthop. 1997;111:606-12.

2. Sari E and Birinci I. Microbiological evaluation of $0,2 \%$ chlorhexidine gluconatemouth rinse in orthodontics patiens. Angle Orthod. 2007;77:8814.

3. Latief HK. Perbandingan efektivitas berkumur dengan larutan teh hijau seduh konsentrasi 100\% dan $25 \%$ dalam menghambat pembentukan plak gigi secara klinis pada enam permukaan gigi (penelitian klinis pada mahasiswa FKG UI Angkatan 2005-2008)[Sripsi]. Jakarta: Universitas Indonesia; 2008. Indonesian.

4. Brightman LJ, Terzhalmy GT, Greenwall H, Jacobs M, Enlow DH. The effects of $0.12 \%$ chlorhexidine gluconate mouth rinse on orthodontic patients aged 11 through 17 with established gingivitis. Am J Orthod Dentofac Orthop. 1991;100:324-9.

5. Prijantojo. Antiseptik sebagai larutan kumur, perannya terhadap pembentukan plak gigi dan radang gusi. Cermin Dunia Kedokteran. 1996;2830. Indonesian.

6. Cacciafesta V, Sfondrini MF, Stifanelli P, Scribante A, Klersy C. Effect of chlorhexidine application on shear bond strength of brackets bonded with a resin modified glass ionomer. Am J Orthod Dentofac Orthop. 2006;129:273-6.

7. Oltramari-Navarro PVP, Titarelli JM, Marsicano JA, Henriques JFC, Janson G, Lauris JRP, et al. Effectiveness of $0.50 \%$ and $0.75 \%$ chlorhexidine dentrifices in orthodontic patients: A double-blind and randomized controlled trial. Am J Orthod Dentofac Orthop. 2009;136:651-6. 
8. Rateischak HK, Wolf HF. Endodontology. Stuttgart: George Thiere Verlag. 1999. p.156.

9. Roberts WR, Addy M. Comparison of the in vivo and in vitro antibacterial properties of antiseptic mouthrinse containing chlorhexidine, alesince, cetypyriclinicum chloride and hexitidine. Relevance to mode action. J. Clin Periodont. 1981;295-310.

10. Kushiyama M, Shimazaki Y, Murakami M, Yamashita Y. Relationship between intake of green tea and periodontal disease. J Periodontol. 2009;80:372-7.

11. Makimura M, Hirasawa M, Kobayashi K, Indo J, Sakanaka S, Taguchi T, Otake S. Inhibitory effect of tea catechins on collagenase activity. J Periodontol. 1993;64:630-6.

12. Indrawati, Rand, Devijanti R. Beda daya anti bakteri kandungan teh hijau dan teh hitam terhadap kuman penyebab karies gigi. Majalah Ilmiah FKG Universitas Trisakti. 1996;967-72. Indonesian.

13. Nirmaladewi A, Handajani J, Tandelilin RT. Status saliva dan gingivitis pada penderita gingivitis setelah kumur epigalocatechin gallate (EGCG) dari ekstrak teh hijau (Camellia Sinensis) [thesis]. Yogyakarta: Gadjah Mada University; 2008. Indonesian.

14. Cohen RL, Alves MEAF, Crawford JM, McSwiggin T, Chambers DA. Association of gingival crevicular fluid aspartate aminotransferase levels with histopathology during ligature- induced periodontitis in the beagle dog.J Dent Res.1991;70:984-7.

15. Embery, Gand, Waddington R. Gingival crevicular fluid: biomarkers of periodontal tissue activity. Adv Dent Res. 1994;8:329-36.

16. Perinetti G, Varvara G, Festa F, Esposito P. Aspartate aminotransferase activity in pulp of orthodontically treated teeth. Am J Orthod Dentofac Orthop. 2004;125:88-92.

17. Insoft M, King GJ, Keeling SD. The measurement of acid and alkaline phosphatase in gingival crevicular fluid during orthodontic tooth movement. Am J Orthod Dentofac Orthop.1996;109:287-96.

18. Chambers DA, Crawford JM, Mukerjee S, Cohen RL. Aspartate aminotransferase in crevicular fluid during experimental gingivitis in beagle dogs. J Periodontol. 1984;55:525-30.

19. Nanda R, Kuhlberg A. Biomechanical basis of extraction space closure. In: Nanda R, editors. Biomechanics in clinical orthodontics. Philadelphia: W.B. Saunders Company; 1997. p. 156-8.

20. Gunawan E. Aktivitas aspartat aminotransferase di dalam cairan celah gusi kaninus pada pergerakan ortodonti [thesis]. Jakarta: Trisakti University; 2009. Indonesian.

21. Tzannetou S, Efstratiadis S, Nicolay O, Grbic J, Lamster I. Comparison of levels of inflammatory mediators IL- $1 \beta$ and $\beta G$ in gingival crevicular fluid from molars, premolars, and incisors during rapid palatal expansion. Am J Orthod Dentofac Orthop. 2008;133:699-707. 